\author{
Prylipko T.M. \\ Doctor of Agricultural Sciences, Professor \\ State Agrarian and Engineering University in Podilya \\ Kamianets-Podilskyi, Ukraine \\ E-mail : vtl280726p@ukr.net
}

\title{
QUALITY CONTROL, SAFETY OF RAW MEAT AND TURKEY MEAT PATE AND JUSTIFICATION OF RECIPES AND STERILIZATION REGIMENS
}

\begin{abstract}
In the study of the toxicity of turkey meat, it was found that the content of toxic elements in the tested batches did not exceed the permitted levels. Thus, the lead content in meat was $0.08 \mathrm{mg} / \mathrm{kg}$, which is 6.2 times $(P<0.05)$ less than the determined norm, the arsenic content was at the level of $0.02 \mathrm{mg} / \mathrm{kg}$ or 5 times $(P<0.05)$ is less than the standard, and cadmium and mercury are not detected at all. Based on the defined function and constraints, we create a spreadsheet in MS Excel according to functional dependency. The built-in Excel Solution Finder was used to determine the optimum composition of components. The purpose of optimizing the recipe composition of the original products is its balance in basic nutrients, the maximum approximation to the following requirements of healthy nutrition is observed at the ratio of proteins: fats: carbohydrates - 1: 1,3: 4; essential amino acids lysine: tryptophan: methionine - 1: 3: 3; fatty acid composition of polyunsaturated: saturated: monounsaturated - 1: 3: 6; Omega 6: Omega 3 - 10: 1; the ratio of trace elements: Ca: $\mathrm{Mg}=1: 1,5$; Ca: $P=1:$ 0.6. The highest percentage (31\%) of canned pate is made from turkey meat, namely turkey meat. The specified meat raw material has undergone laboratory testing and meets the requirements of quality and safety regulations. Beef liver is included in the recipe in the amount of $10 \%$ of the total mass of raw materials and at its nutritional value complements the quality indicators of pate. In order to give a gentle texture to the pate, a fermented pork skin in the brine is put into the recipe. The indices of mass fraction of moisture of rock were $66.8 \%(P<0.01)$, fat - 20.0\% ( $P<0.01)$, protein $-8.2 \%(P<0.01)$, ashes $-1.46 \%(P<0.01)$, carbohydrates $3.5 \%(P<0.01)$ and are within the limits specified by the regulatory documentation. The caloric content of the meat pate is low and is only $226.8 \mathrm{kcal}$. The results of studies of turkey meat pate showed that the mass concentration of toxic elements meets regulatory standards, in particular the lead content was $0.02 \mathrm{mg} / \mathrm{kg}(P$ $<0.03)$ or 30 times less than the allowable level, cadmium - $0.01 \mathrm{mg} / \mathrm{kg}(P<0.01)$ or 30 times less, arsenic $0.05 \mathrm{mg} / \mathrm{kg}(P<0.01)$ or 20 times less, mercury - $0.005 \mathrm{mg} / \mathrm{kg}(P<0.01)$ or 20 times less. Indicators of organochlorine pesticide content were in particular the gamma isomer of HCG-0.04 mg $/ \mathrm{kg}(P<0.01)$ or 2.5 times less than normal, DDT and its metabolites - $0.03 \mathrm{mg} / \mathrm{kg}(P<0.05)$ or 3.3 times less.
\end{abstract}

Keywords: acid; meat pate; quality;protein,;laboratory testing; parameters; toxic elements;components

Introduction. At the present stage of development of the meat processing industry, there is an increase in the production of new types of meat products, which include multicomponent emulsions, suspensions, gels and structured compositions, which are made of recycled protein content. It is worth noting that existing pate formulations are increasingly interested in exploring the possibility of using non-traditional raw materials and raw materials that can provide high quality canned pies. At the same time it is possible to note such kind of raw materials as turkey meat, which, in turn, can be attributed to dietary, and products made from it to delicacy $[9$,$] .$

Recently, many experts have been paying attention to the need for accelerated development of indications in Ukraine. They indicate that after the saturation of the broiler market, it is necessary to expand the range of meat products and increase the production of meat of other types of poultry - ducks, geese, and especially turkeys $[4,6]$. 
Analysis of world trends in poultry shows [1, 7] the stable pattern of increasing production and consumption of turkey.

Recently, aseptic preservation has been in wide demand. The basis of this method [5] laid a new principle of thermal sterilization of food. By developing a new method of aseptic preservation, it has become possible to intensify the heat treatment of the product and, as a result, to reduce its detrimental effect on the quality of the preserved product. However, although the aseptic method of preservation is one of the promising methods, it has not yet become widespread in the practice of canning production for various reasons, one of which being the technical complexity of creating aseptic conditions when packing and sealing the product in packaging, and the fact that this the method can be used for cans of homogeneous consistency.

Also, the way to sterilize products in the stream is in great demand. In the manufacture of canned foods of products having a homogeneous structure, it is possible to use heat treatment of the product in the stream as it moves in the product pipeline [9]. The products are heated in heat exchangers of various types (tubular, plate rotators, etc.). Such heat treatment can be used for practically cans of homogeneous consistency and, moreover, is associated with packaging difficulties that do not preclude secondary contamination of the product with microflora.

Material and methodology of research. The purpose of the experimental studies is to confirm the theoretical prerequisites for the process of sterilization of canned meat pate, to optimize its recipe composition and to determine the optimal mode parameters of the equipment under investigation, while improving the quality characteristics of the original products.

Experimental studies were carried out by conventional and standard methods used to study the physicochemical and bacteriological parameters of meat products [3].

Organoleptic evaluation of the products was carried out according to a modified Tilgner method DE [1]. Due to the fact that new technologies and formulations of meat pate with biologically active substances were developed, it became necessary to develop scales of private qualities of their organoleptic evaluation. The quality of the combined protein-containing products was evaluated by a five-point tasting panel. The main indicators were taken into account: appearance, section view, texture, taste, color, smell. Tables were developed where each quality metric was matched by its characteristics.

Nitrite studies were performed according to DSTU ISO2918: 2005. The method is based on the Grissay reaction [3].

Research results. Antibiotics include products of life of microorganisms, as well as their semi-synthetic derivatives and synthetic analogues, which in the body suppress or adversely affect pathogens. When ingested, antibiotics alter the intestinal microflora, which disrupts the synthesis of vitamins and multiplies pathogenic microorganisms. According to the obtained laboratory analyzes, turkey meat, which is sent for the production of meat pies, contains no residues of antibiotics and can be used in the production of meat products.

Pesticides include pesticides, which are widely used in the field of plant and animal husbandry. When pesticides get into the human body with food, they have a general toxic effect, affect the liver, kidneys, nervous system. The studies were performed using the physicochemical method of chromatography, which consists in the separation of complex content of multicomponent mixtures. The high resolution of these methods makes it possible to separate substances that are similar in nature, structure and properties. This explains the widespread use of chromatography in various areas of research, in laboratory practice, in industry, and the like. The results of the studies are shown in table 1.

The quantitative analysis of the results of the experiments shows that the content of isomers of hexachlorocyclohexane in turkey meat is $0.02 \mathrm{mg} / \mathrm{kg}$, which is 5 times $(\mathrm{P}<0.01)$ below the acceptable values. DDT and its metabolites are $0.03 \mathrm{mg} / \mathrm{kg}$, which is 3.3 times (P 
$<0.01)$ below normal. Therefore, based on studies on the content of pesticide residues, we can assume that turkey meat is suitable for the production of meat pies.

Table 1. Pesticide content in turkey meat $(M \pm m, n=3)$

\begin{tabular}{|c|l|l|l|}
\hline № & \multicolumn{1}{|c|}{ List of indicators } & \multicolumn{1}{c|}{ Laboratory analysis } & $\begin{array}{c}\text { Requirements of the regulatory } \\
\text { document }\end{array}$ \\
\hline 1 & $\begin{array}{l}\text { Hexachlorocyclohexane (alpha, beta, } \\
\text { gamma isomers) }\end{array}$ & $0,02 \pm 0,03 \mathrm{mg} / \mathrm{kg}$ & not more than $0.1 \mathrm{mg} / \mathrm{kg}$ \\
\hline 2 & DDT and its metabolites & $0,03 \pm 0,04 \mathrm{mg} / \mathrm{kg}$ & not more than $0.1 \mathrm{mg} / \mathrm{kg}$ \\
\hline
\end{tabular}

Toxic elements include heavy metals and arsenic, which have high toxicity and the ability to accumulate in the human body. Among the toxic elements, the most threatening to human health are four: lead, cadmium, arsenic and mercury, which are able to accumulate in the human body and cause diseases that manifest themselves gradually, without pronounced symptoms, and have high biological activity, oligodynamic, oligodynamic cumulative properties, the presence of specific, including remote, effects on the body.

In the study of the toxicity of turkey meat, it was found that the content of toxic elements in the tested batches did not exceed the permitted levels. Thus, the lead content in meat was $0.08 \mathrm{mg} / \mathrm{kg}$, which is 6.2 times $(\mathrm{P}<0.05)$ less than the determined norm, the arsenic content was at the level of $0.02 \mathrm{mg} / \mathrm{kg}$ or 5 times $(\mathrm{P}<0.05)$ is less than the standard, and cadmium and mercury are not detected at all.

One of the main indicators of safety of the selected raw material is the presence of mesophilic aerobic and optional anaerobic microorganisms (MAFAnM) in it. Mesophilic aerobic and optional anaerobic microorganisms are called microorganisms, the optimal growth temperature of which is $25-40{ }^{\circ} \mathrm{C}$ under conditions of oxygen access (aerobic) or its absence (anaerobic). The determination of the amount of mesophilic aerobic and optional anaerobic microorganisms was performed by counting colonies growing on solid nutrient medium after incubation at $30^{\circ} \mathrm{C}$.

According to laboratory studies, the raw material found does not contain MAFanM colonies and is therefore safe for the production of meat products. Thus, on the basis of complex analysis of turkey meat, we can conclude that the safety of meat raw materials for the production of pies of high quality and nutritional value.

Regardless of the methods used, the formulation and justification of the formulations involves the following steps: formulation of requirements for the ingredients and product that meet the task; selection of ingredients that provide the desired product properties; setting acceptable levels (smallest and highest fractions) of the ingredient in the formulation; determining the optimal levels of ingredients in the recipe.

The task of calculating the optimal formulation was formulated as follows: with known lists of ingredients that are acceptable for the production of a particular product, and the characteristics of each of them (content of moisture, fat, protein, amino acids, fatty acids, trace elements, cost, etc.), as well as the required mass of the obtained of the product, it is necessary to determine in what quantities it is expedient to include the ingredients in the formulation in order to meet the established requirements for the chemical composition, quality of the finished product and the amount of use of the individual ingredients or combinations thereof, to provide the minimum (maximum) value of the optimization criterion $[2,8]$.

The following steps were consistently performed: data collection, systematization and analysis according to the characteristics of the selected list of ingredients and product requirements; calculation of variants of the optimal formulation with the selected optimization criterion and set restrictions; verification of the variant obtained for the possibility of improving 
the optimization criterion and KZB and / or FSW and / or MEM; comparative analysis of the calculated variants of the formulations and the choice of them for experimental verification [9].

We create a mathematical model for the calculation of raw materials for pate recipe. The purpose of optimizing the recipe composition of the original products is its balance in basic nutrients, the maximum approximation to the following requirements of healthy nutrition is observed at the ratio of proteins: fats: carbohydrates - 1: 1,3: 4; essential amino acids lysine: tryptophan: methionine - 1: 3: 3; fatty acid composition of polyunsaturated: saturated: monounsaturated - 1: 3: 6; Omega 6: Omega 3 - 10: 1; the ratio of trace elements: $\mathrm{Ca}: \mathrm{Mg}=1$ : 1,5; Ca: $\mathrm{P}=1: 0.6$.

The result of the mathematical analysis was the development of five virtual models of canned pate recipes. A comprehensive evaluation of the formulations obtained showed that the fifth model is optimal, with a maximum value of this indicator of 3.0.

Table 2. Ingredients composition and characteristics of virtual recipe models

\begin{tabular}{|c|c|c|c|c|c|}
\hline \multirow{2}{*}{ Name of ingredients or indicators } & \multicolumn{5}{|c|}{ Virtual recipes models } \\
\hline & I & II & III & IV & $\mathrm{V}$ \\
\hline 1 & 2 & 3 & 4 & 5 & 6 \\
\hline \multicolumn{6}{|l|}{ Formulations, $\%$} \\
\hline Beef liver & 20,0 & 0 & 40,0 & 10,0 & 10 \\
\hline Turkey meat & 0 & 25,0 & 7,7 & 17,2 & 31,0 \\
\hline Fat is melted & 25,0 & 0 & 15,0 & 31,9 & 16,7 \\
\hline Sunflower oil & 0 & 25,0 & 0 & 0,2 & 0 \\
\hline The pork skin is fermented & 15,0 & 10,0 & 0 & 8,7 & 16,7 \\
\hline Beef brains & 10,0 & 10,0 & 12,0 & 0 & 0 \\
\hline Soy protein & 0 & 0 & 1,5 & 0 & 3,0 \\
\hline Chickpeas & 0 & 3,0 & 0 & 1,5 & $\begin{array}{c}0 \\
00\end{array}$ \\
\hline Wheat fiber & 0 & 0 & 0 & 1,0 & 0 \\
\hline Wheat flour & 5,0 & 2,0 & 4,0 & 2,5 & 0 \\
\hline Dried onions & 1,0 & 1,0 & 0 & 1,0 & 0,8 \\
\hline Water added & 21,4 & 21,4 & 17,2 & 23,4 & 20,35 \\
\hline Nutritional supplements & 1,5 & 1,5 & 1,5 & 1,5 & 0 \\
\hline Spices & 0 & 0 & 0 & 0 & 0,35 \\
\hline Salt & 1,1 & 1,1 & 1,1 & 1,1 & 1,1 \\
\hline Sugar & 0 & 0 & 0 & 0 & 0 \\
\hline Together & 100 & 100 & 100 & 100 & 100 \\
\hline \multicolumn{6}{|c|}{ Chemical composition, $\%$} \\
\hline Moisture & 53,64 & 50,64 & 61,90 & 46,86 & 64,68 \\
\hline Fat & 29,50 & 33,53 & 19,10 & 37,84 & 13,71 \\
\hline Protein & 8,15 & 8,07 & 10,48 & 7,45 & 13,01 \\
\hline Including balanced & 7,02 & 6,99 & 8,61 & 6,53 & 11,19 \\
\hline Carbohydrates & 5,96 & 2,97 & 5,76 & 4,10 & 5,51 \\
\hline Ratio M: F: C & $1: 3,64: 0,73$ & $1: 4,15: 0,37$ & $1: 1,82: 0,50$ & $1: 5,08: 0,55$ & $1: 1,05: 0,42$ \\
\hline \multicolumn{6}{|c|}{ Amino acid composition, $\mathrm{g}$} \\
\hline Valine & 0,404 & 0,348 & 0,692 & 0,324 & 0,664 \\
\hline Isoleucine & 0,318 & 0,333 & 0,547 & 0,283 & 0,531 \\
\hline Leucine & 0,557 & 0,584 & 0,953 & 0,499 & 0,931 \\
\hline Lysine & 0,475 & 0,522 & 0,830 & 0,444 & 0,816 \\
\hline Methionine + cystine & 0,142 & 0,152 & 0,250 & 0,132 & 0,244 \\
\hline Threonine & 0,283 & 0,272 & 0,476 & 0,232 & 0,460 \\
\hline Tryptophan & 0,087 & 0,109 & 0,150 & 0,089 & 0,152 \\
\hline Phenylalanine + tyrosine & 0,327 & 0,321 & 0,548 & 0,277 & 0,533 \\
\hline Minimum score, (methionine) & 0,498 & 0,538 & 0,682 & 0,506 & 0,536 \\
\hline Balance factor & 0,563 & 0,592 & 0,579 & 0,592 & 0,579 \\
\hline Correlation & $1: 0,3: 0,18$ & $1: 0,29: 0,21$ & $1: 0,3: 0,18$ & $1: 0,3: 0,2$ & $1: 0,30: 0,19$ \\
\hline
\end{tabular}


Подільський вісник: сільське господарство, техніка, економіка
Podilian Bulletin: agriculture, engineering, economics

\section{Continuation of Table 2}

\begin{tabular}{|c|c|c|c|c|c|}
\hline \multicolumn{6}{|c|}{$\begin{array}{c}1 \\
\text { Fatty acid composition, } g\end{array}$} \\
\hline Saturated fatty acids $(\mathrm{H})$ & 11,25 & 5,03 & 7,07 & 14,32 & 4,62 \\
\hline Monounsaturated fatty acids (M) & 12,70 & 8,88 & 7,91 & 16,69 & 5,20 \\
\hline Polyunsaturated fat acids $(\mathrm{P})$ & 3,27 & 3,75 & 2,32 & 4,41 & 1,77 \\
\hline The ratio $\mathrm{P}: \mathrm{M}: \mathrm{S}$ & $1: 3,88: 3,44$ & $1: 2,37: 1,34$ & $1: 3,41: 3,04$ & $1: 3,78: 3,25$ & $1: 2,93: 2,61$ \\
\hline Or $(\mathrm{P}+\mathrm{M}) / \mathrm{S}$ & 1,42 & 2,51 & 1,45 & 1,47 & 1,51 \\
\hline \multicolumn{6}{|c|}{ Trace element composition, mg } \\
\hline Calcium $(\mathrm{Ca})$ & 4,4 & 11,5 & 12,2 & 7,7 & 12,7 \\
\hline Phosphorus (P) & 123,8 & 95,1 & 204,7 & 77,7 & 185,4 \\
\hline Magnesium & 7,9 & 12,1 & 16,3 & 9,6 & 16,8 \\
\hline The ratio of $\mathrm{Ca}: \mathrm{P}: \mathrm{Mg}$ & $1: 28: 1,79$ & $1: 8,3: 1,05$ & $1: 1,6: 1,34$ & $1: 10: 1,25$ & $1: 14,6: 1,34$ \\
\hline \multicolumn{6}{|c|}{ Estimates: } \\
\hline Calorie content, kcal & 321,0 & 338,0 & 236,0 & 386,0 & 198,0 \\
\hline \multicolumn{6}{|c|}{ Relative metrics: } \\
\hline Protein balance & 0,643 & 0,625 & 0,769 & 0,583 & 1,0 \\
\hline $\begin{array}{l}\text { The ratio of unsaturated to saturated } \\
\text { fatty acids }\end{array}$ & 0,940 & 0,600 & 0,960 & 0,973 & 1,0 \\
\hline Calorie content & 0,617 & 0,586 & 0,839 & 0,513 & 1,0 \\
\hline $\begin{array}{l}\text { Comprehensive assessment of } \\
\text { formulations }\end{array}$ & 2,2 & 1,811 & 2,568 & 2,069 & 3,0 \\
\hline
\end{tabular}

Based on the results of experimental studies, we developed a recipe for meat pate of dietary orientation, presented in table 3 .

Table 3. The best recipe for turkey meat pate

\begin{tabular}{|l|c|}
\hline \multicolumn{1}{|c|}{ Name } & Mass fraction of components, $\%$ \\
\hline Turkey meat & 31,000 \\
\hline Beef liver & 10,000 \\
\hline Pork stud & 16,700 \\
\hline Soy (flour) & 3,000 \\
\hline The pork skin is modified & 16,700 \\
\hline Fresh or dried onions & 0,800 \\
\hline Salt is kitchen food & 1,100 \\
\hline Black pepper ground & 0,070 \\
\hline Coriander & 0,070 \\
\hline Nutmeg & 0,070 \\
\hline Carnation & 0,070 \\
\hline Cinnamon & 0,070 \\
\hline Water & 20,350 \\
\hline Together & 100 \\
\hline
\end{tabular}

According to Table 3, the highest percentage (31\%) of canned pate is made from turkey meat, namely turkey meat. Beef liver is included in the recipe in the amount of $10 \%$ of the total mass of raw materials and at its nutritional value complements the quality indicators of pate. In order to give a gentle texture to the pate, a fermented pork skin in the brine is put into the recipe.

Sterilization of turkey pate is carried out according to the formula - $(\mathrm{A}-\mathrm{B}-\mathrm{C}) / \mathrm{T}=$ (25-40-25) / 115. Production control is the main means of monitoring the correctness of the technological process and its correction. Constant and properly organized control of production gives an opportunity to monitor the quality of finished products, to prevent deviations from the physical and chemical norms and allows to ensure the production of products that meet the requirements of the standards. Physical, chemical, biochemical and physico-chemical methods are used to accomplish these tasks. 
According to the data of physicochemical studies the indices of mass fraction of moisture of rock were $66.8 \%(\mathrm{P}<0.01)$, fat $-20.0 \%(\mathrm{P}<0.01)$, protein $-8.2 \%(\mathrm{P}<0.01)$, ashes $1.46 \%(\mathrm{P}<0.01)$, carbohydrates $-3.5 \%(\mathrm{P}<0.01)$ and are within the limits specified by the regulatory documentation. The caloric content of the meat pate is low and is only $226.8 \mathrm{kcal}$.

Table 4. Results of physicochemical indices of turkey meat pate $(M \pm m, n=5)$

\begin{tabular}{|l|c|}
\hline \multicolumn{1}{|c|}{ Indicators } & Contents, \% \\
\hline Wet & $66,8 \pm 0,5$ \\
\hline Fat & $20,0 \pm 0,25$ \\
\hline White & $8,2 \pm 0,09$ \\
\hline Ash & $1,46 \pm 0,02$ \\
\hline Carbohydrates & $3,5 \pm 0,03$ \\
\hline Calorie content, kcal. & $226,8 \pm 1,0$ \\
\hline
\end{tabular}

The results of studies of turkey meat pate showed that the mass concentration of toxic elements meets regulatory standards, in particular the lead content was $0.02 \mathrm{mg} / \mathrm{kg}(\mathrm{P}<0.03)$ or 30 times less than the allowable level, cadmium $-0.01 \mathrm{mg} / \mathrm{kg}(\mathrm{P}<0.01)$ or 30 times less, arsenic $-0.05 \mathrm{mg} / \mathrm{kg}(\mathrm{P}<0.01)$ or 20 times less, mercury $-0.005 \mathrm{mg} / \mathrm{kg}(\mathrm{P}<0.01)$ or 20 times less.

Indicators of organochlorine pesticide content were in particular the gamma isomer of HCG - $0.04 \mathrm{mg} / \mathrm{kg}(\mathrm{P}<0.01)$ or 2.5 times less than normal, DDT and its metabolites $-0.03 \mathrm{mg}$ $/ \mathrm{kg}(\mathrm{P}<0.05)$ or 3.3 times less. The residues of antibiotics and radionuclides were not detected at all. According to the results of studies on the safety indices, turkey meat pate meets the requirements of SanPiN.

Conclusions. 1. As a result of the mathematical analysis, five virtual models of canned pate formulations were developed. A comprehensive evaluation of the formulations obtained showed that the fifth model is optimal, with a maximum value of this indicator of 3.0.

2. Comparative analysis of the composition and thermal regimes of similar pate products shows that the proposed recipe for canned turkey meat has the optimal composition of ingredients that ensure the balance of the chemical composition of the product for its most complete absorption by the human body. The thermal process of sterilization of the studied meat pate analogues has a tougher effect on the product and is extended over time by 10-15 minutes, which ultimately has a negative effect on the nutritional value of the product.

\section{References}

1. Ibatullin I.I., Zhukorsky, O.M., Bashchenko, M.I., etc. (2017). Methodology and organization of scientific studies in creativity: a tool. Kyiv: Agrarian Science. [in Ukranian].

2. Ibatullin I.I., Melnyk, Y.F., Otchenashko, V.V. et al. (2015). Workshop on Feeding Farm Animals: Educ. tool. Kyiv. [in Ukranian].

3. National Standard of Ukraine "Meat and meat products. Method for the determination of total nitrite content (control method) (ISO 2918: 1975, IDT): DSTU ISO 2918: 2005” (2010). Kyiv, Ukraine: State Consumer Standard of Ukraine. [in Ukranian].

4. Prylipko, T.M., \& Kucius, V.M. (2014). Substantiation of regime parameters of the process of sterilization of canned meat. Coll. Sciences. Proceedings of the Odessa National Academy of Food Technologies: Technical Sciences, 46 (2), 177-182. [in Ukranian].

5. Prylipko T.M., \& Kutsiy, V.M. (October 8-9, 2013). Development of turkey meat production technology. Topical Issues of the Food Industry. Paper presented at the All-Ukrainian Scientific and Technical. Conference, TNTU them. Ivan Pulia, Ternopil, Ukraine (pp. 166-168). [in Ukranian].

6. Prylipko, T.M., Kutsiy, V.M. (2013). Ukraine Patent No. 84152, IPC9 A23B4/00. The regime of sterilization of canned pates. Kyiv, Ukraine: Ukrainian Intellectual Property Institute. [in Ukranian].

7. Prylipko, T.M., \& Kutsiy, V.M. (2013). State Consumer Standard of Ukraine No. 132 Pate canned from turkey meat "Podilsky": TU 10.1-22769675-001: 2013. Lviv, Ukraine: State Scientific- 
Research Control Institute of Veterinary Medicinal Products and Feed Additives.

8. Dyall, S.C., \& Michael-Titus, A.T. (2008). Neurological Benefits of Omega-3 Fatty Acids. Neuromolecular Med, 10 (4), 219-235.

9. Hartmann C., Mathmann K., Delgado A. (2006). Mechanical stresses in cellular structures under high hydrostatic pressure. Innovative Food Science and Emerging Technologies, 7(12), 1-12.

10. Prylipko, T., Bukalova, N., \& Lyasota, V. (2019). Features of introduction of the HACCP system on enterprises of Ukraine. In The potential of modern science: volume 1 (pp.49-60). London.

Received 08/02/2019

Revision 11/02/2019 Accepted November 12/27/2019 